\title{
Households' Demand for Better Solid Waste Disposal Services: Case Study of Four Communities in the New Juaben Municipality, Ghana
}

\author{
Mustapha Alhassan ${ }^{1} \&$ Jamal Mohammed $^{2}$ \\ ${ }^{1}$ Department of Agricultural Economics, University of Nebraska, Lincoln, NE, USA \\ ${ }^{2}$ Department of Liberal Studies, Koforidua Polytechnic, Koforidua, Eastern Region, Ghana \\ Correspondence: Mustapha Alhassan, Department of Agricultural Economics, 102 Filley Hall, University of \\ Nebraska, Lincoln, NE 68503, USA. Tel: 1-402-617-0153. E-mail: malhassan@huskers.unl.edu
}

\author{
Received: August 12, 2013 Accepted: October 1, 2013 Online Published: October 9, 2013 \\ doi:10.5539/jsd.v6n11p16 URL: http://dx.doi.org/10.5539/jsd.v6n11p16
}

\begin{abstract}
This paper uncovers the demand of households in four communities (Srodae, Effiduase, Koforidua-ada, and Betom) in the New Juaben Municipality in Ghana for better solid waste disposal services. The study used the Contingent Valuation Method (CVM) and the respondents were selected by means of simple random sampling for interviewing. The Willingness to Pay (WTP) was elicited using single bounded Dichotomous Choice (DC) format and the data were analyzed using the probit model as one of the efficient and priori superior procedures used in analyzing binary response data. The median WTP was GHC 2.23 (US\$ 1.13) per household per month and the mean WTP was GHC 3.67 (US\$ 1.85) per household per month. The most significant and influencing factors that affect WTP in this study are the environmental safety concern of the respondent, level of satisfaction of current waste disposal services, education, household size, length of stay in the current residence, walking time to public dumpster, and sex of respondent.
\end{abstract}

Keywords: willingness to pay, solid waste disposal, New Juaben Municipality

\section{Introduction}

Rapid population growth and urbanization in general have led to serious solid waste generation in most cities worldwide. Municipal solid waste globally, increased by at least 7\% annually between 2003 and 2006 (United Nations Environment Programme [UNEP], 2009). And according to Global Waste Management Market Report (2007), municipal solid waste generated globally was estimated to be 2.02 billion tonnes in 2006 and was expected to increase by $37.3 \%$ between 2007 and 2011. In developing countries, municipal solid waste is not well managed because cities and municipalities cannot cope with the accelerated pace of waste production (Modak, 2010). This global threat of solid waste disposal has shown its ugly face in Africa.

Souring population growth in Africa has increased solid waste generated by households which far exceed the collection capacity. A survey by the United States Agency for International Development (USAID) in 2009 purged the rate of solid waste generated in Africa at approximately 0.5 kilograms per person per day. And only a small amount of these solid wastes are properly disposed of in designated landfills. The rest are either dumped openly without recourse to treatment systems or left in public dumpsters with no one to properly dispose them. Greater amount of these solid wastes are left to litter on the edges of cities and towns, which however cannot decompose and hence cause environmental health problems and discomfort.

In Ghana, a major problem that confronts urban cities is solid waste disposal and is a particularly worrying issue that seems to overwhelm the authorities. Tamakloe (2006) as cited in Anthony (2009) asserted that, the menace of solid waste disposal has threatened the achievement of the seventh Millennium Development Goals and thus makes the achievement of this blue-print target date of 2015 impossible. According to Demographic and Health Survey conducted in 2008 by Ghana's Water and Sanitation Sector Monitoring Platform (WSMP), Ghana was able to achieve $12.4 \%$ for improved sanitation for this period. This figure was quite lower compared with other development indicators like improved drinking water for 2008 which was $83.8 \%$. In addition, more than half $(56.5 \%)$ of households in the Eastern Region dispose of solid waste in public dumps, while a quarter (25.2\%) dump their household waste anywhere (Ghana Statistical Service, 2000). 
In a September 2007 Modern Ghana News press release, the New Juaben Municipal Chief Executive, Nana Adjei Boateng, revealed that the municipality was generating an average of about 40 tonnes of solid waste and 67860 liters of liquid waste each day, causing the Municipal Assembly an average of about GHC 100 million monthly on waste management. Poor solid waste disposal has threatened the lives of the inhabitants of the New Juaben Municipality. There is increased pressure for dumping of household solid waste at public dump places due to increased household size, thereby straining the management capabilities of regulatory authorities, waste collectors and other resources. Currently, spilled waste on streets in the municipality is a common sight. This open dumping of waste causes foul smell, breeds diseases such as diarrhea, skin and eye irritations, and spoils the public image of the New Juaben Municipality, especially in the selected communities. To help reduce the environmental hazards associated with the improper management of solid waste in developing countries, policy makers should be advised on how much households are willing to collaborate efforts to do so. Hence, it is in the right direction to study households' demand for better/improved solid waste disposal services.

Willingness to pay for improved solid waste management has been opined severally in environmental literature as a way of dealing with the aforementioned menace of solid waste but not much is espoused about solid waste disposal services in Ghana. The contingent valuation method has been a technique used to elicit respondents' willingness to pay for improved solid waste disposal services in both developed and developing countries.

A study by Ojok , Koech, Tole, and Okot-Okumu (2013) estimated households' willingness to pay (WTP) for improved municipal solid waste management services in Kampala, Uganda. The study employed a dichotomous choice contingent valuation (CV) technique and used a logit regression model in their data analysis to obtain the mean and the median WTP of the households. The results of their study revealed that $48.1 \%$ of households in Kampala were willing to pay for improved municipal solid waste management services with a mean monthly WTP of UGX 5382 (US\$2.91). The factors in their study which influenced the WTP significantly were gender in which females were willing to pay more than males, household size, education level, income level, marital status and migration status.

In a related study, Hagos, Makonnen, and Gebreegziabher (2012) estimated households' willingness to pay for improved urban waste management in Mekelle City, Ethiopia, using a cross-sectional survey of 226 randomly selected households. Their study employed Tobit and Probit models in the empirical analysis to determine the factors that influence households WTP for improved Solid Waste management. The mean WTP from their analysis based on their dichotomous choice questions was ETB 11.89 which is less than US\$ 1 . The results of their study revealed that, respondents' WTP for improved solid waste management was significantly related to income and awareness of environmental quality, among other factors. And in Malaysia, Murad and Raquib (2007) also used CV to determine the WTP of the poor for improved access to solid waste collection and disposal services in the city of Kuala Lumpur. The study used stratified random sampling in gathering the data and simple multiple linear regressions in the data analysis. The mean WTP from their study was MYR 13.00. The most significant factors in their study that affect WTP were respondents satisfaction with present waste collection services, income of respondents, gender, length of stay of residents in the house, and dependency ratio.

The general objective of this study is to use the CV technique to assess households' demand for better solid waste disposal services in the selected communities. Better solid waste disposal services in this case can best be described as making sure waste collectors would pick up the waste from homes (or establishment) each day; the waste from all the houses (or establishments) subscribing to the service would be disposed of properly; the waste would be hauled away from the neighborhood in trucks to a municipal landfill; and the waste would not be left around the neighborhood in rubbish heaps or municipal bins. The estimated WTP values would help the researchers to recommend to policymakers and implementers as to the way forward in dealing with solid waste disposal practices in the study area and even beyond.

\subsection{Hypotheses}

In addition to estimating the WTP, the study was intended to test the following hypotheses:

a. $\mathrm{H}_{0}$ : Household's that are concerned about environmental safety or acceptability of final disposal of solid waste are not willing to pay for better solid waste disposal services.

b. $\mathrm{H}_{0}$ : Households that are dissatisfied with current waste disposal services are not willing to pay for better waste disposal services.

c. $\mathrm{H}_{0}$ : A household with a farther distance to the public disposal container is not willing to pay for better solid waste disposal services. 


\section{Materials and Methods}

The Contingent Valuation Method (CVM) was used in this study. It is the most common method used in valuing nonmarket resources including environmental quality improvement programs. In the CVM, individuals are simply asked to state their WTP for the nonmarket resource through WTP surveys. The CVM was recommended by the National Oceanic and Atmospheric Administration (NOAA) Panel in 1993 as a dependable method for valuing nonmarket resources. The cogency of the CVM results, however, depends on several factors including the response format, the payment vehicle, the scenario, and the survey design in general (see Boyle, 2003). This study employed CVM because the solid waste disposal program is both environmental and nonmarket resource. The program is also hypothetical with no available data which makes CVM suitable for the study.

The survey questionnaire was designed to follow the World Bank's guidance on survey questionnaires design to assess demand and WTP of consumers (see Cointreau-Levine \& Coad, 2000).

The questionnaire was divided into four sections after the introduction. The introduction explained the nature of the better solid waste disposal services to the respondents. Followed by the four sections: Section A or the Identification section, section B or the existing situation regarding solid waste disposal in the communities, section $\mathrm{C}$ or the improved solid waste disposal program and WTP, and section D or the other information. Specific questions were asked under each section to simply aid the researchers in testing the hypotheses for this study.

In section A, respondent's household as well as the position of the respondent were simply identified. The respondent was also asked how long she/he lived in the residence. Section B carried the questions on the walking time of the respondent to the public dumpster, concerns of the respondents about the environmental safety and level of satisfaction of the current disposal services. Section C demanded the respondent to answer yes/no question as to whether she/he was willing to pay an additional amount when the program is implemented. Section D carried the sociodemographic information of the respondent.

\subsection{The Theoretical Model}

Improved solid waste disposal service is a program intended to enhance environmental quality in the study area. To achieve this, each individual is required to give up some amount of her/his income as a waste disposal fee without changing her/his utility levels. Using the compensating welfare measure, the utility levels are the status quo utility level and the utility level after the program is implemented. These utility levels can be expressed using the equation below:

$$
\mathrm{v}\left(\mathrm{P}^{\mathrm{o}}, \mathrm{q}^{\mathrm{o}}, \mathrm{I}\right)=\mathrm{v}\left(\mathrm{P}^{1}, \mathrm{q}^{1}, \mathrm{I}-\mathrm{c}\right)
$$

where $\mathrm{v}$ is the maximized level of utility (indirect utility), $\mathrm{P}^{\mathrm{o}}$ is the waste disposal fee at the status quo level of environmental quality, $\mathrm{P}^{1}$ is the waste disposal fee after the implementation of the program, $\mathrm{q}^{0}$ is the status quo level of environmental quality, $\mathrm{q}^{1}$ is the environmental quality level after the program is implemented, $\mathrm{I}$ is the income of the individual, and c (compensating variation) is the amount the individual agreed to pay after the implementation of the program.

\subsection{The Empirical Models}

The WTP elicitation technique used in this study is the single bounded Dichotomous Choice (DC) format. The DC question asks the respondent whether she/he is willing to pay a specific amount for the program when it is implemented. There are many other response formats such as the open or closed ended, and the payment card. The choice of response format is believed to impact the WTP estimates positively or negatively. Meanwhile, Loomis (1990) and Boyle et al. (1996) argued that both the open-ended and the dichotomous choice formats produce reliable results. The DC format is the most widely used format and appears to be more preferred to the other response formats because it reduces the cognitive burden placed on the respondent, and also mimics a real market transaction (Food and Agricultural Organization [FAO], 2000). The DC format has its own weaknesses including its inability to directly infer the respondent's exact WTP amount, but it may still give better results when the data are well analyzed (Boyle, 2003). Assuming the individual's true value, $y_{i}^{*}$, from the DC data can be expressed using the model:

$$
y_{i}^{*}=z_{i}^{\prime} \beta+u_{i}
$$

where $z_{i}^{\prime}$ is a vector of independent variables including the socioeconomic characteristics of the respondent, $\beta$ is the vector of coefficients to be estimated, and $u_{i}$ is the zero-mean error term. Equation (2) is only useful when Ordinary Least Squares (OLS) estimation is suitable. But the OLS is not priori superior in this case as compared to Maximum Likelihood Estimation (MLE) procedure because the WTP values are not observed and there is a 
probability of the individual's true value, $y_{i}^{*}$, being located above or below her/his WTP bid if the individual said "yes" or "no" respectively (Alberini, 1995). In that case, OLS would give biased parameter estimates as well as aggregate valuation results. WTP is nonnegative and log normal so the logarithmic transformation of the WTP should be considered (Cameron \& Huppert, 1989; Alberini, 1995).

Following Alberini (1995), proper analysis of the DC data can proceed as follows:

Given an individual's response and characteristics, the probability is $\operatorname{Pr}\left(y_{i}^{*} \geq \mathrm{c}_{\mathrm{i}} \mid z_{i}^{\prime}\right)=1-\mathrm{G}\left(\mathrm{c}_{\mathrm{i}} \mid z_{i}^{\prime}\right)$, where $\mathrm{G}$ is the cumulative distribution function (cdf) of $\mathrm{y}^{*}$. And because $\mathrm{y}^{*}$ is normal or logistic in practice, the probability of "yes" to a payment of GHC $\mathrm{c}_{i}$ is $\operatorname{Pr}\left(\mathrm{y}_{i}=1\right)=\mathrm{E}\left(\mathrm{y}_{i}\right)=\operatorname{Pr}\left(y_{i}^{*}>\mathrm{c}_{i}\right)=1-\mathrm{F}\left(\left(\mathrm{c}_{i}-z_{i}^{\prime} \beta\right) / \sigma\right)$, where $\mathrm{y}_{i}$ is an indicator variable if the respondent takes the offer $\mathrm{c}_{i}$, and zero otherwise. $\mathrm{F}$ is the cdf of $\mathrm{u}_{i} / \sigma$, and $\sigma$ is the scale parameter of the distribution of $\mathrm{y}^{*}$. The probability of no to a payment is $\operatorname{Pr}\left(y_{i}^{*} \leq \mathrm{c}_{\mathrm{i}}\right)=\mathrm{F}\left(\left(\mathrm{c}_{i}-z_{i}^{\prime} \beta\right) / \sigma\right.$.

The log likelihood function is then:

$$
\log \mathrm{L}=\sum_{i=1}^{n}\left\{y i \log \left[1-\mathrm{F}\left(\mathrm{c}_{i}-z_{i}^{\prime} \beta\right) / \sigma\right]+(1-\mathrm{y} i) \log \mathrm{F}\left[\left(\mathrm{c}_{i}-z_{i}^{\prime} \beta\right) / \sigma\right]\right\}
$$

Equation (3) is estimated using MLE procedure or simply Probit which is one of the more robust and efficient estimation procedures in DC data analysis.

Following Cameron and Huppert (1989), the mean and the median WTP values are computed by first finding the fitted values of $\log y_{i}^{*}$ after the probit regression. The conditional mean of $\log y_{i}^{*}$ is expressed in the form $z_{i}^{\prime} \beta$ and $\exp \left(z_{i}^{\prime} \beta\right)$ is used to retransform $\log y_{i}^{*}$ into $\mathrm{y}$, which represents the median WTP value. Scaling the median WTP value by $\exp \left(\sigma^{2} / 2\right)$ gives the mean WTP value, where $\sigma$ is the standard error of the estimate.

\subsection{The Study Area, Sampling Methodology, and Data Collection}

The New Juaben Municipality is located in the Eastern Region of Ghana. Figure 1is the map of the Eastern Ghana Districts in which the New Juaben Municipality is located. The New Juaben Municipality is made up of 23 communities. The study was designed to cover four of these communities: Srodae, Effiduase, Koforidua-ada, and Betom. These communities are the main communities that are well known to produce more solid waste in the municipality, but have less desirable means of getting rid of the solid waste. The total number of households in each community was not available at the time of this study.

The sampling method used was simple random sampling, and the respondents were interviewed face-to-face which is the most convenient way of conducting surveys in the study area. The survey took place from July 27 to August 3, 2013. Fifty households were randomly selected from each community making up 200 households for the entire study. In practice, most studies determine the sample size of their study based on the given budget (Boyle, 2003), and this was how the sample size for this study was determined. Moreover, contingent valuation studies on solid waste disposal services have not been conducted in the study area before. Their existence could have been helpful in determining the sample size based on the standard error. It was realized that, each community has a main road dividing it into almost two equal halves. So the interviewers ensured they randomly selected 25 households from each side of the main road making sure the locations of the selected households covered all parts of the area. The interviewers selected every other fifth household for interviewing. To avoid interviewing only a particular group of respondents such as the unemployed, seniors or retirees, the interviewers visited the communities at different times of the day. The interviewers encountered very few nonresponses from some family members but were able to still interview other members of those families when they varied their visiting times. The 200 questionnaires were administered within the survey period. 


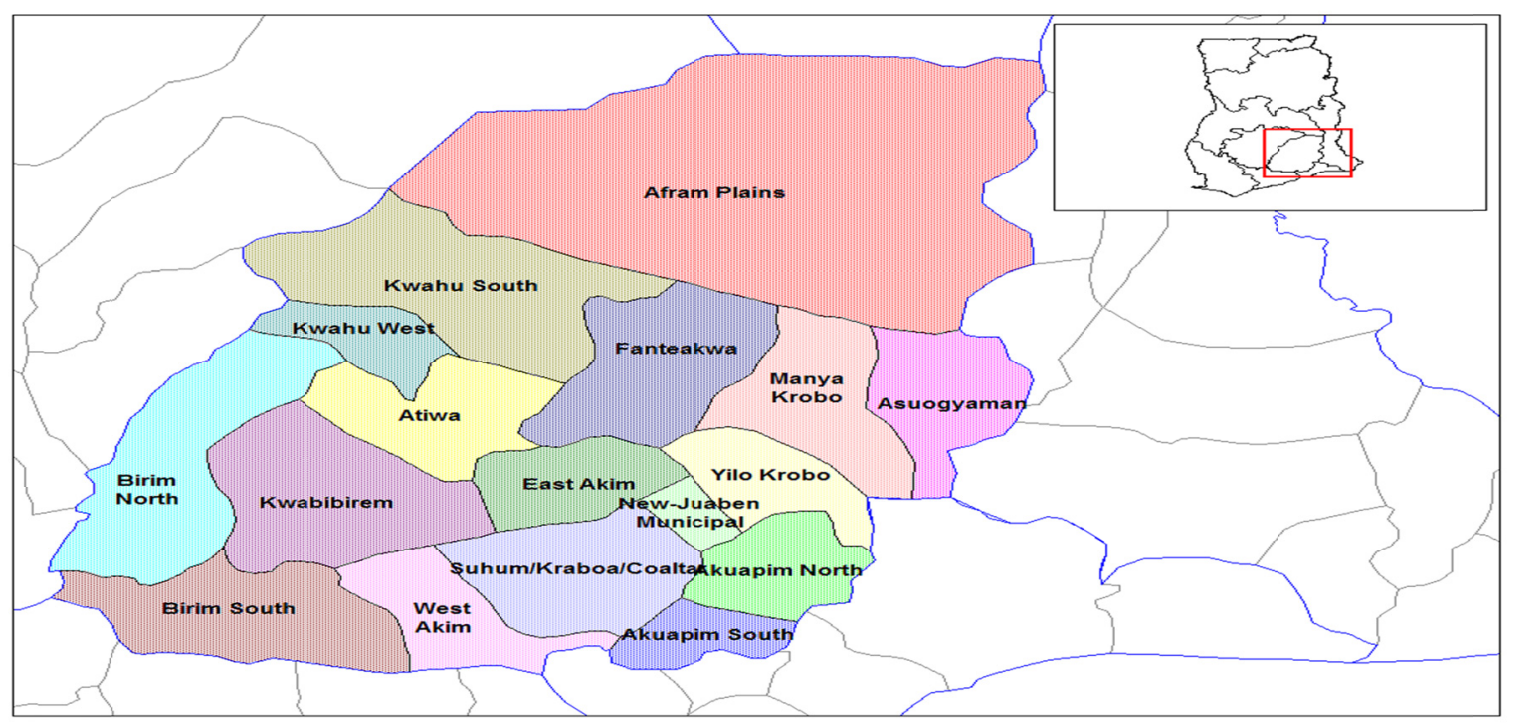

Figure 1. Map of Eastern Ghana Districts

Source: http://en.wikipedia.org/wiki/File:Eastern_Ghana_districts.png

\section{Results}

\subsection{Socioeconomic Characteristics of the Respondents}

Characteristics of the respondents are presented in Table 1. STATA 11 was used for the entire data analysis. From a total of 200 respondents, $75 \%$ were females and the rest were males. The average age of the respondents was about 45 years. Forty one percent of the respondents were between the ages of 35 and $44,49 \%$ were between the ages of 45 and 55 and $10 \%$ were between the ages of 55 and 64, but none was above 65 years of age. The average education of the respondents was Middle/Junior High School. 50.5\% of the respondents were with no formal education, $6 \%$ attended primary school and the rest attended either Middle/Junior High school or beyond with 32.5 percent holding either bachelor's degree or diploma, but no masters and above. The average household size was about 3 , the minimum household size was 2 and the maximum was 6 . The average total income of a household in Ghana Cedis (GHC) was about GHC 3500 for the year 2012, the minimum being GHC 1000 and the maximum being about GHC 5500.

\subsection{Willingness to Pay}

In Table 2 are the WTP bids that were posed to respondents and the percentage of yes responses. The WTP bids in Ghana Cedis (GHC) were GHC 2, GHC 5, GHC 8, and GHC 10. These bids were chosen based on an open ended pretest. The pretest question simply asked the respondent to state the amount she/he would be willing to pay for improved solid waste disposal services. The closed ended or the single bounded dichotomous choice format requires that respondents are presented with different bids. From the pretest results, GHC 2 was then chosen as the bid for the majority of the respondents with the assumption that respondents would be less willing to pay for the program if the waste disposal fee is too high. Other bids were also shown to respondents but no respondent was shown with more than one bid amount. Out of the respondents who were presented GHC 2, 92.5\% accepted the program, $93.3 \%$ of those who were presented GHC 5 accepted the program, $41.7 \%$ of those who were presented the GHC 8 accepted the program, and 5.6\% of those who were presented GHC 10 accepted the program. In all, $74 \%$ of the total respondents accepted the program. 
Table 1. Socioeconomic characteristics of respondents $(n=200)$

\begin{tabular}{|c|c|c|c|c|c|}
\hline Characteristic & $\%$ & Characteristic & $\%$ & Characteristic & $\%$ \\
\hline Gender & & $\begin{array}{l}\text { Total Income of } \\
\text { Household }\end{array}$ & & Education & \\
\hline Male & 25 & $<$ GHC 1000 & 2.5 & No formal education & 50.5 \\
\hline Female & 75 & GHC 1000 to 2000 & 17.5 & Primary school & 6 \\
\hline Age & & GHC 2000 to 3000 & 22 & Middle/JHS & 5 \\
\hline Under 24 & 0 & GHC 3000 to 4000 & 18 & High school & 6 \\
\hline $25-34$ & 0 & GHC 4000 to 5000 & 18.5 & Bachelor/Tertiary & 32.5 \\
\hline $35-44$ & 41 & $>$ GHC 5000 & 21.5 & Masters and above & 0 \\
\hline $45-54$ & 49 & & & & \\
\hline $55-64$ & 10 & & & & \\
\hline Over 65 & 0 & & & & \\
\hline
\end{tabular}

Table 2. WTP Bids and Percentage of Yes Responses $(n=200)$

\begin{tabular}{ccc}
\hline Bid (GHC) & Number & \% of Yes Responses \\
\hline 2 & 107 & 92.5 \\
5 & 45 & 93.3 \\
8 & 12 & 41.7 \\
10 & 36 & 5.6
\end{tabular}

Table 3. Definition of selected variables

\begin{tabular}{|c|c|}
\hline Variable & Definition \\
\hline Walkingtime & One way walking time from the household to the dumpster in minutes \\
\hline Opinion & $\begin{array}{l}\text { Respondent's opinion about existing waste disposal services: } 1=\text { not satisfied at all, } 2= \\
\text { Reasonably satisfied, } 3=\text { very much satisfied, } 4=\text { Don't know }\end{array}$ \\
\hline environmentalsafety & $\begin{array}{l}\text { Respondent's concern about environmental safety } \\
1=\text { Not concerned, } 2=\text { Somewhat concerned, } 3=\text { Very concerned }\end{array}$ \\
\hline Wtp & WTP bid in GHC \\
\hline lnwtp & Logarithm of the WTP bid \\
\hline Sex & Dummy variable $=1$ for male, 0 for female \\
\hline Age & $\begin{array}{l}\text { Age of respondent in years } \\
1=<24 \text { years, } 2=25 \text { to } 34,3=35 \text { to } 44,4=45 \text { to } 54,5=55 \text { to } 64,6=>65\end{array}$ \\
\hline Education & $\begin{array}{l}\text { Level of education of respondent: } 1=\text { no formal educ., } 2=\text { primary school, } 3= \\
\text { middle/junior high school, } 4=\text { high school, } 5=\text { first degree, } 6=\text { second degree and } \\
\text { above }\end{array}$ \\
\hline Householdsize & Number of family members \\
\hline Householdincome & Total income of household for the year 2012 \\
\hline & $\begin{array}{l}1=<\mathrm{GHC} 1000,2=\mathrm{GHC} 1000 \text { to } 2000,3=\mathrm{GHC} 2000 \text { to } 3000,4=\mathrm{GHC} \\
3000 \text { to } 4000,5=\mathrm{GHC} 4000 \text { to } 5000,6=>\mathrm{GHC} 5000\end{array}$ \\
\hline Contributiontoincome & Number of family members who contribute to total household income \\
\hline lengthofstay & $\begin{array}{l}\text { Number of years respondent stayed in the current residence: } 1=<5 \text { years, } 2=5 \text { to } 10 \\
\text { years, } \\
3=10 \text { to } 15 \text { years, } 4=15 \text { to } 20 \text { years, } 5=>20 \text { years }\end{array}$ \\
\hline
\end{tabular}


Table 4. Descriptive statistics $(n=200)$

\begin{tabular}{ccccc}
\hline Varibale & Mean & Std. Dev. & Min & Max \\
\hline Walkingtime & 4.745 & 4.0980 & 1 & 20 \\
Opinion & 2.565 & 0.589502 & 2 & 4 \\
Environmentalsafety & 1.1 & 0.4370 & 1 & 3 \\
Wtp & 4.475 & 3.1028 & 2 & 10 \\
Lnwtp & 1.2722 & 0.6613 & 0.693 & 2.3026 \\
Sex & 0.25 & 0.4341 & 0 & 1 \\
Age & 3.69 & 0.6450 & 3 & 5 \\
Education & 2.64 & 1.824016 & 1 & 5 \\
Householdsize & 3.37 & 0.8225 & 2 & 5 \\
Householdincome & 3.97 & 1.483274 & 1 & 6 \\
Contributiontoincome & 1.805 & 0.6777 & 1 & 6 \\
Lengthofstay & 2.82 & 1.0598 & 1 & 5 \\
\hline
\end{tabular}

Table 5. Probit estimates of WTP

\begin{tabular}{|c|c|c|}
\hline Variable & Coefficients & Standard Error \\
\hline Constant & $\begin{array}{c}32.1099 * * * \\
(3.27)\end{array}$ & 9.8053 \\
\hline walkingtime & $\begin{array}{c}8.1414 * * * \\
(2.76)\end{array}$ & 2.9551 \\
\hline Opinion & $\begin{array}{c}-13.6787^{* * *} \\
(-2.96)\end{array}$ & 4.6282 \\
\hline environmentalsafety & $\begin{array}{c}20.8245 * * * \\
(2.77)\end{array}$ & 7.5156 \\
\hline $\operatorname{lnwtp}$ & $\begin{array}{c}-9.5416^{* * *} \\
(-3.54)\end{array}$ & 2.6943 \\
\hline Sex & $\begin{array}{c}-11.6879^{* * *} \\
(-2.64)\end{array}$ & 4.4262 \\
\hline Age & $\begin{array}{l}-2.2699 \\
(-2.38)\end{array}$ & 0.9555 \\
\hline Education & $\begin{array}{c}1.3583^{* * *} \\
(2.60)\end{array}$ & 0.5228 \\
\hline Householdsize & $\begin{array}{c}-10.3045^{* * *} \\
(-2.74)\end{array}$ & 3.7599 \\
\hline householdincome & $\begin{array}{l}0.3200 \\
(1.12)\end{array}$ & 0.2866 \\
\hline contributiontoincome & $\begin{array}{l}2.5010 \\
(-0.11)\end{array}$ & 1.2623 \\
\hline lengthofstay & $\begin{array}{c}2.7855^{* * * *} \\
(2.65)\end{array}$ & 1.0510 \\
\hline Standard Error of Estimate & & 1.0000 \\
\hline Log likelihood & -34.2492 & \\
\hline LR chi2(11) & $160.72 * * *$ & \\
\hline Average median WTP & GHC 2.23 & \\
\hline Average mean WTP & GHC 3.67 & \\
\hline
\end{tabular}

Note: $* * *=$ significance at $1 \%$ level; Values in parentheses are $\mathrm{t}$-values. 


\section{Discussion}

In Table 3 are the definitions of the selected variables, Table 4 is the descriptive statistics, and Table 5 are the results of the probit regression estimates. The variables were selected based on the hypotheses the researchers wanted to test for. All the selected variables except householdincome, age, and contributiontoincome are significant. Walkingtime is significant at $1 \%$ level and positively relate to WTP which makes sense because respondents who spend much time in walking to dump their waste are willing to pay more for the improvement than those who spend less time walking to dump their waste. The opinion variable is also significant at $1 \%$ level and negatively correlated with WTP which indicates that, respondents who are not satisfied with the current waste disposal services have higher WTP than those who are satisfied. The environmentalsafety variable is also significant at $1 \%$ level and positively correlates with WTP indicating that, respondents who are concerned with the environmental safety and acceptability of the current waste disposal services are willing to pay more for the improved waste disposal program.

The Inwtp, and householdsize variables are negatively correlated with WTP and significant at $1 \%$ level. These indicate that respondents posed with higher WTP bids are likely to reject the program as compared to those posed with lower WTP bids. And smaller household size respondents are willing to pay more than larger households. The sex variable is also significant at $1 \%$ and has a negative sign based on how the sex variable was coded. This implies that women are willing to pay more for the program than men. The rest of the variables are education, and lengthofstay. All these variables are positively related to WTP and significant at 1\%.

\section{Conclusions}

The intent of this research was to uncover the demand of the residents in the four communities (Srodae, Effiduase, Koforidua-ada, and Betom) in the New Juaben Municipality for better solid waste disposal services. From the results, the median WTP was GHC 2.23 (US\$ 1.13) per household per month and the mean WTP was GHC 3.67 (US\$ 1.85) per household per month. As at the time this paper was written, US\$ 1 traded for about GHC 1.98. The median WTP is the additional cost of the program to the respondents that would secure $50 \%$ majority vote while the mean WTP is the amount each respondent would be willing to pay. The mean can help policy makers to determine the total benefits of the program when it is multiplied by total number of the population or the program participants. The significant variables in the study that are identified to have impacts on WTP are walkingtime, opinion, environmentalsafety, Inwtp, sex, education, householdsize, and lengthofstay. Respondents who are concerned about environmental safety and acceptability of current waste disposal, dissatisfied with the current waste disposal services, highly educated, and stayed longer in their current residence were willing to pay more for the better solid waste disposal services. While households with larger family sizes were not willing to pay for the program.

Comparing the above findings to the previous studies on improved solid waste disposal services, the mean WTP from this study is very closed to those of Ojok et al. (2013), Hagos et al. (2012), and Murad and Raquib (2007). In addition, the factors which significantly influence the WTP of the households in this study appear to match with those in the previous studies, which imply that this study may be somewhat reliable. The results from this study, however, cannot be generalizable. In other words, may not be applicable to the entire New Juaben Municipality but may serve as a leeway to the next steps in research in the area regarding WTP for better solid waste disposal services, such as benefit-cost analysis to determine better solid waste management practices in the Municipality.

\subsection{Limitations to the Study}

Although this research achieved its aims and objectives, it was not without limitations and shortcomings. First, this study is limited in both scope and space such that it was only meant to estimate the WTP of households for better solid waste disposal services in only the 4 selected communities out of 23. Second, the research was constrained by inadequate funds. If funds were available, increasing the number of communities as well as the sample size could make the results more generalizable. Third, the research was constrained in handling only the disposal of households' solid waste but not how these solid wastes are generated and what specifically they are. And finally, time required to conduct this study was limited and put more pressure on both interviewers and respondents to get the work done within the stipulated time. Such undue pressure on both the interviewers and respondents could bias responses.

\subsection{Recommendations}

The researchers recommend that the next step should be to conduct benefit-cost analysis in order to determine whether revenues that would be generated based on the mean WTP from this study would be able to offset the 
cost of implementing the program. The municipality should also create environmental awareness in the communities and emphasize the need to have cleaner environment through cost sharing. Communal labor is another common way people can contribute their time towards environmental cleanliness and may also be emphasized in the area. To make the results of another study in the area more generalizable, it would be better to increase the number of communities in the municipality as well as the sample size. Using a double bounded DC format in eliciting the WTP may also be helpful since it is believed to increase efficiency in locating the true WTP of respondents. Computing the WTP of each community could have also been helpful in order to find out differences in WTP based on where respondents reside.

\section{References}

Alberini, A. (1995). Optimal Designs for Discrete Choice Contingent Valuation Surveys: Single-Bound, Double Bound, and Bivariate Models. Journal of Environmental Economics and Management, 28, 287-306. http://dx.doi.org/10.1006/jeem.1995.1019

Anthony, B. (2009). Urban Environmental Problems in Ghana: A case study of Social and Environmental Injustice in Solid Waste Management in Accra and Second-Takoradi. PhD Thesis submitted to the University of Nothingham. UK.

Boyle, K. J. (2003). Contingent Valuation in Practice. In P. A. Champ, K. J. Boyle, \& T. C. Brown (Eds.), A Primer on Nonmarket Valuation (pp. 111-158). Dordrecht, Netherlands: Kluwer Academic Publishers. http://dx.doi.org/10.1007/978-94-007-0826-6_5

Boyle, K. J., Johnson, F. R., McCollum, D. W., Desvousges, W. H., Dunford, R. W., \& Hudson, S. P. (1996). Valuing Public Goods: Discrete Versus Continuous Contingent-Valuation Responses. Land Economics, 72, 381-396. http://dx.doi.org/10.2307/3147204

Cameron, T. A., \& Huppert, D. D. (1989). OLS versus ML Estimation of Non-market Resource values with Payment Card Interval Data. Journal of Environmental Economics and Management, 17, 230-246. http://dx.doi.org/10.1016/0095-0696(89)90018-1

Cointreau-Levine, S., \& Coad, A. (2000). Private Sector Participation in Municipal Solid Waste Management, Guidance Pack. St. Gallen, Swizerland. Retrieved from http://www.worldbank.org/urban/solid_wm/erm/CWG\%20folder/Guidance\%20Pack\%20TOC.pdf

Food and Agricultural Organization. (2000). Applications of the contingent valuation method in developing countries. Retrieved from http://www.fao.org/docrep/003/x8955e/x8955e03.htm

Global Waste Management Market Report. (2007). Retrieved from http://www.seas.columbia.edu/earth/wtert/sofos/Key_Global_Waste_Generation.pdf

Hagos, D., Makonnen, A., \& Gebreegziabher, Z. (2012). Households' Willingness to Pay for Improved Urban Waste Management in Makelle City, Ethiopia. Environment for Development. Discussion Paper Series. Retrieved from http://www.rff.org/RFF/Documents/EfD-DP-12-06.pdf

Loomis, J. (1990). Comparative Reliability of the Dichotomous Choice and Open-Ended Contingent Valuation $\begin{array}{lllll}\text { Techniques. Journal of Economics and Management, } & 18, & \text { 78-85. }\end{array}$ http://dx.doi.org/10.1016/0095-0696(90)90053-2

Modak, P. (2010). Municipal Solid Waste Management: Turning waste into resources. Shanghai Manual - A Guide for Sustainable Urban Development in the $21^{\text {st }}$ Century. Retrieved from http://www.un.org/esa/dsd/susdevtopics/sdt_pdfs/shanghaimanual/Chapter\%205\%20-\%20Waste_managem ent.pdf

Modern Ghana News. (2007). New Juaben Municipal Assembly Launches Tax Campaign. Retrieved from http://www.modernghana.com/news/142305/1/new-juaben-municipal-assembly-launches-tax-educati.html

Murad, M. W., \& Raquib, M. A. (2007). Willingness of the Poor to Pay for ImprovedAccess to Solid Waste Collection and Disposal Services. Journal of Environment and Development, 16(1), 84-101. http://dx.doi.org/10.1177/1070496506297006

National Oceanic and Atmospheric Administration NOAA Panel. (1993). Report of the NOAA Panel on Contingent Valuation. Washington D.C.

Ojok, O. J., Koech, M. K., Tole, M., \& Okot-Okumu, J. (2013). Households' Willingness to Pay for Improved Municipal Solid Waste Management Services in Kampala, Uganda. Science Journal of Environmental 
Engineering Research. Volume 2013, Article ID sjeer-143, $8 \quad$ Pages, 2012. http://dx.doi.org/10.7143/sjeer/143.

Republic of Ghana Demographic and Health Survey. (2000). Final Report.

Republic of Ghana Statistical Service. (2000). Population and Housing Census in Ghana.

United Nations Environment Programme (UNEP). (2009). Developing Integrated Solid Waste Management Plan. Assessment of Current Waste Management System and Gaps therein, 2.

United States Agency for International Development (USAID). (2009). Solid Waste: generation, handling, treatment and disposal. Environmental Guidelines for Small-Scale Activities in Africa (EGSSAA). Retrieved from www.encapafrica.org

\section{Copyrights}

Copyright for this article is retained by the author(s), with first publication rights granted to the journal.

This is an open-access article distributed under the terms and conditions of the Creative Commons Attribution license (http://creativecommons.org/licenses/by/3.0/). 